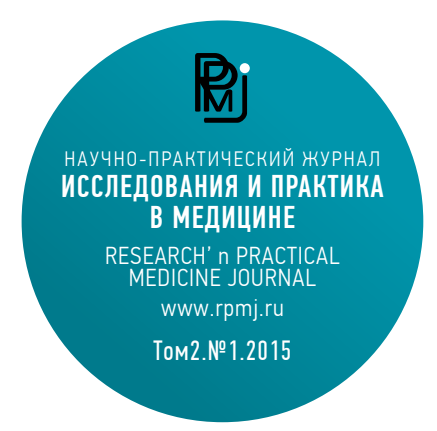

Ключевые слова:

эхинококкоз однокамерный, гельминтозы, паразитарные болезни

Keywords:

single chamber echinococcosis, helminth infections,

parasitic diseases

DOI:10.17709/2409-2231-2015-2-1-27-35

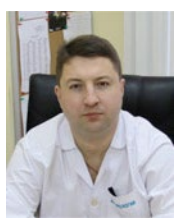

Для корреспонденции:

Поляков Николай Васильевич -

к. М.Н., заведующий отделом реконструктивной

урологии с группой микрохирургии

и урологической травмы НИИ урологии

и интервенционной радиологии

им. Н. А. Лопаткина - филиал ФГБУ «НМИРЦ»

Минздрава России

Адрес: 105425, Российская Федерация,

г. Москва, ул. 3-я Парковая, д 51 стр. 4

Телефон: +7 (495) 164-13-44;

+7 (495) 154-12-68

E-mail: nikp73@bk.ru

Статья поступила 10.02.2015,

принята к печати 05.03.2015

For correspondence:

Polyakov Nikolay Vasilyevich -

$\mathrm{PhD}$, head of department of reconstructive urology

with microsurgical group of urological trauma

N. Lopatkin SRIUIR

Address: 51-4, 3-ya Parkovaya, Moscow,

Russian Federation, 105425

Tel: +7 (495) 164-13-44;

+7 (495) 154-12-68

E-mail: nikp73@bk.ru

\section{ОДНОКАМЕРНЫЙ (ГИДАТИДНЫЙ) ЭХИНОКОККОЗ}

\author{
Поляков Н.В, Ромих В.В., Сафаров Р.В., Поляков В.Е.
}

НИИ урологии и интервенционной радиологии им. Н.А. Лопаткина - филиал ФГБУ «НМИРЦ» Минздрава России (Москва, Российская Федерация)

105425, Российская Федерация, г. Москва, ул. 3-я Парковая, д. 51, стр. 4.

\section{Резюме}

Эхинококкоз однокамерный (эхинококкоз гидатидный) -- тяжелое хроническое паразитарное заболевание, гельминтоз, вызываемый личиночной стадией цепня Echinococcus granulosus, характеризующееся развитием паразитарных кист в печени, реже в легких, а также в других органах и тканях. Представлена этиология заболевания, охарактеризован возбудитель и цикл его развития, окончательные и промежуточные хозяева, строение и морфология эхинококковой кисты. Описаны географическое распространение гельминтоза, патогенез, иммунитет, клиническая картина, эхинококкоз печени (бессимптомная, неосложненная стадии и стадия осложнений), эхинококкоз легких (начальная стадия и стадия развернутой клинической картины), других органов. Приведены клинические наблюдения эхинококкоза однокамерного у девочки 10 лет и мальчика 9 лет. Диагностика включает эпидемиологические, анамнестические и клинические данные, изменения лабораторных показателей, инструментальные методы, методы лучевой диагностики, иммунодиагностики, паразитологической диагностики. Основным методом лечения остается хирургический. Описана фармакотерапия альбендазолом в комбинации с хирургическим методом и в качестве вынужденного самостоятельного вида лечения. Подробно описана диспансеризация больных после лечения, эпидемиология гельминтоза и основные современные меры профилактики.

\section{SINGLE CHAMBER (HYDATID) ECHINOCOCCOSIS}

Polyakov N.V., Romikh V.V., Safarov R.V., Polyakov V.E.

N. Lopatkin SRIUIR (Moscow, Russian Federation)

51-4, 3-ya Parkovaya, Moscow, Russian Federation, 105425

\section{Summary}

The unilocular echinococcosis (hydatid disease)is the severe chronic parasitic disease, helminthiasis caused by the larval stage of the tapeworm Echinococcus granulosus, characterized by the development of parasitic cysts in the liver, rarely in the lungs and in other organs and tissues. The etiology of the disease, characterized by the pathogen and its development cycle, final and intermediate hosts, structure and morphology of the hydatid cyst. They describe the geographic distribution of helminth infections, pathogenesis, immunity, clinical picture, echinococcosis of the liver (asymptomatic, uncomplicated stage and stage of complications), echinococcosis of the lungs (the initial stage and the stage of developed clinical picture), other bodies. Clinical observation of unilocular echinococcosis in a 10 year old girl and a 9 year old boy. Diagnosis includes epidemiological, anamnestic and clinical data, changes in laboratory parameters, instrumental methods, diagnostic methods, immunodiagnostics, parasitological diagnosis. The surgery remains the main method of treatment. They described pharmacological therapy with albendazole in combination with a surgical method and as an involuntary self-treatment. A detailed clinical examination of patients after treatment, epidemiology of helminth infections and the major modern preventive measures. 
Эхинококкозы - группа личиночных гельминтозов-зоонозов. Однокамерный (гидатидный) эхинококкоз - тяжелое хроническое заболевание, характеризующееся развитием паразитарных кист преимущественно в печени, реже в легких, а также в других органах и тканях. Эхинококкоз может осложняться разрывом кисты и развитием анафилактического шока (Лысенко, 2002; Поляков, 2003; Ветшев, Мусаев, 2006; Сергиев и др., 2008; Ветшев и др., 2013).

\section{Этиология}

Еще врачи древности упоминали заболевание, которое в настоящее время носит наименование эхинококкоз. Гиппократ описал поражение печени при этом заболевании как «печень, наполненную водой». Ученые того времени принимали эхинококковые кисты за расширение лимфатических сосудов и называли их гидатидами.

Установить паразитарную природу заболевания удалось после того, как П.С. Паллас в 1760 г. обнаружил имагинальную (половозрелую) стадию пузыревидного эхинококка, паразитирующего в кишечнике хищников. В 1786 г. Бачем открыл личиночные стадии эхинококков (ларвоцист), развивающихся в тканях копытных и человека. В 1801 г. опубликовал свою работу Рудольфи. В ней он изложил пути проникновения паразита в организм человека, подробно описал самого паразита и предложил в его названии использовать термин "эхинококк». В 1833 г. Сайболд описал шестикрючный зародыш эхинококка. В 1850 г. опубликовал свою работу Лейкарт, в ней он доказал связь зародыша эхинококка с последующим возникновением заболевания и установил, что эхинококковый пузырь является личиночной стадией развития этого ленточного червя. В 1862 г. в работе Э. Островского было описано воспроизведение половозрелой формы паразита у собак при кормлении их эхинококковыми цистами, взятыми от человека, что послужило доказательством, что человек является промежуточным хозяином паразита.

Возбудителем эхинококкоза учеловека и животных является личиночная стадия цепня Echinococcus granulosus. После попадания ларвоцист (личиночной, пузырчатой стадии эхинококка) в организм плотоядных животных окончательных хозяев паразита - эхинококк развивается до половозрелой стадии медленно, за 70-100 дней.

Согласно современной классификации, эхинококк относится к надтипу низших червей - Scolecida, типу плоские черви - Plathelmintes, классу - ленточные черви (цестоды) - Cestoda, отряду - Cyclophyllidea, подотряду - Taeniata, семейству - Taeniidae, роду - Echinococcus, виду - Echinococcus granulosus.

Окончательными хозяевами E. granulosus являются представители семейства псовых: собака, шакал, волк, динго, лисица, койот, гиена и др., в кишечнике которых паразитируют половозрелые эхинококки длиной 3,4-6,2 мм, шириной 0,47-0,98 мм, состоящие из головки (сколекса), имеющей 4 присоски и двойную корону крючьев (38-40 крючьев), шейки и 3-4 члеников. Последний, зрелый членик, имеет матку, содержащую 400-800 яиц округлой или овальной формы, диаметром
0,030-0,036 мм. Внутри яйца содержится онкосфера с толстой оболочкой и шестикрючным зародышем. 3релые членики отходят с экскрементами, часть выползает активно. Отошедшие с экскрементами членики подвижны и могут расползаться в радиусе 20-30 см, обсеменяя окружающую среду онкосферами.

Промежуточными хозяевами являются различные копытные и человек. В организме человека и животных (чаще - овец) развивается личиночная стадия эхинококка.. При попадании в желудочно-кишечный тракт яиц паразита их наружная оболочка под действием пищеварительного сока растворяется. Освободившаяся онкосфера с помощью крючьев проникает в слизистую оболочку желудка или кишки, откуда с током венозной крови или лимфы переносится в портальную систему и задерживается в печени. Около 70\% зародышей оседает в печени, остальные проходят через печень и попадают в малый круг кровообращения. В легких задерживается около $20 \%$ зародышей, а остальные попадают в большой круг кровообращения и заносятся в другие органы (мышцы, селезенку, почки, губчатые кости и др.)

Осевшая в тканях онкосфера в течение 5 мес. превращается в личинку (ларвоцисту, эхинококковую кисту) диаметром 5-20 мм, имеющюю две оболочки. Наружная кутикулярная оболочка - опалесцирующая, молочно-белого цвета, состоит из множества концентрических слоистых гиалиновых пластинок, что хорошо определяется под микроскопом и служит диагностическим признаком эхинококкозной кисты. Внутренняя оболочка - герминативная - имеет клеточное строение. Основная ее функция - продуцировать сколексы. Количество сколексов в одном пузыре бывает от нескольких десятков до нескольких сотен. Они плавают в жидкости и образуют так называемый гидатидный песок. Иногда в эхинококковом пузыре обнаруживаются «дочерние», а внутри них -«внучатые» пузыри, имеющие такое же строение, как и основной пузырь. Вокруг эхинококкового пузыря в результате реакции тканей хозяина формируется плотная фиброзная капсула (Абдиев и др., 2000; Алиев, Ордабеков, 1996; Скрябин, Шульц, 1929).

\section{Географическое распространение}

Эхинококкоз однокамерный распространен во всех странах мира с пастбищным животноводством, особенно овцеводством (Аргентина, Австралия, Уругвай, Парагвай, Греция, Северная Африка, Азия).

В России эхинококкоз однокамерный часто регистрируется в Башкортостане, Татарстане, Ставропольском, Краснодарском, Алтайском, Красноярском, Хабаровском краях, Волгоградской, Самарской, Ростовской, Оренбургской, Челябинской, Томской, Омской, Магаданской, Амурской областях, на Чукотке.

На территории стран, ранее являвшимися республиками Советского Союза, наибольшее число больных регистрируется в Молдавии, республиках Южного Кавказа, Казахстане (Алма-Атинская и Павлодарская области), Киргизии, Узбекистане (Каракалпакия, Наманганская и Ферганская области), Туркмении (Ашхабадская область, Ташауз, Мары, Чарджоу), на юге Украины. 


\section{Патогенез, иммунитет}

На первых этапах развития зародыша эхинококка в тканях наблюдается мононуклеарная реакция. К 3-5 мес эхинококковый пузырь вполне сформирован и его размеры могут достигать до 40-50 мм.

Основное патологическое воздействие эхинококка на организм человека связано с сенсибилизирующим и механическим факторами. В пораженном органе развивается хронический воспалительный процесс, формируется фиброзная капсула. Наружный слой ее богат кровеносными сосудами, которые окружены большим количеством эпителиоидных, плазматических, гигантских клеток, эозинофилов.

Активизация клеточных механизмов защиты в начальной стадии развития процесса направлена на уничтожение паразита, что в некоторых случаях заканчивается гибелью эхинококкового пузыря с последующим обызвествлением. При недостаточности иммунного ответа происходит рост и развитие паразитарной кисты. В процессе развития эхинококкоза происходит нарастание иммунодефицита, что способствует прогрессированию процесса.

При длительном и далеко зашедшем процессе с образованием множественных и огромных кист, содержащих до нескольких литров жидкости, наиболее выражено их механическое и травмирующее действие. Параллельно длительно и постепенно происходит механическое сдавление воротной или нижней полой вены, желчных протоков, что приводит к застойным явлениям (редко - к желтухе), а в дальнейшем - к развитию цирроза.

Гистологически в печеночной ткани вблизи такой сформировавшейся гигантской кисты отмечается нарушение строения печени, образование соединительно-тканных промежутков между дольками, частичная их атрофия. В соединительной ткани вокруг сосудов и желчных протоков обнаруживаются различные фазы хронического воспаления: круглоклеточная инфильтрация, развитие грануляционной ткани. Такие глубокие изменения в паренхиме печени приводят к изменениям состава белковых компонентов крови (диспротеинемия с гипоальбуминемией). При внепеченочной локализации кист эхинококка гипергаммаглобулинемия, как правило, не проявляется. По-видимому, это и является причиной отрицательных иммунологических реакций при локализации эхинококка в легких.

При тяжелом течении эхинококкоза с рецидивами наблюдаются множественные поражения.

На первом месте среди осложнений стоит нагноение кисты, затем - ее разрыв.

При нагноении паразит погибает, и дальнейшее течение процесса в основном бывает таким же, как при обычном абсцессе. В случае разрыва кисты развивается картина анафилактического шока, а в последующем может возникнуть множественный эхинококкоз брюшной или плевральной полостей, происходит диссеминация процесса в другие отделы пораженного легкого или в другое легкое.

Самоизлечение эхинококковых кист легких иногда наблюдается у коренного населения Чукотки и неко- торых других северных регионов. Причиной являются особенности таксономии паразита в этих территориях (песцовый штамм, участие диких копытных в циркуляции возбудителя, генетические особенности населения ит. п.)

Другим благоприятным исходом является кальцификация кист. Относительно факторов, способствующих кальцификации кист, известно мало, по-видимому, это связано с активизацией клеточного звена иммунитета. Такой исход, несомненно, бывает чаще, чем предполагают, поскольку случайные находки небольших обызвествленных кист нередки, при этом инвазия от момента заражения до самоизлечения может протекать совершенно бессимптомно.

Клиническая картина при эхинококкозе полиморфна и определяется локализацией, размерами кист, скоростью роста, распространенностью процесса, степенью сдавления окружающих органов и тканей. Эхинококкоз печени клинически можно разделить на 3 стадии:

1. начальная или бессимптомная,

2. неосложненная (появление симптомов заболевания при неосложненных кистах),

3. стадия осложнений - выраженные патологические изменения и осложнения.

Бессимптомная стадия - период, когда киста еще очень мала и находится в толще паренхимы печени. Выявляется случайно при ультразвуковом исследовании (сонографии) или рентгенографии.

Неосложненная стадия. В этот период выявляется увеличение печени за счет роста кисты. В случае, если поражение печени множественное или кисты очень большие, печень увеличивается во всех размерах. Иногда в этот период наблюдаются крапивница, эозинофилия крови и другие аллергические проявления.

Одними из первых бывают жалобы на тяжесть в правом подреберье, боли. Тупые боли возникают вследствие растяжения глиссоновой капсулы растущей кистой, сдавления сосудистых образований печени, соседних органов. Причиной острых болей является развитие воспалительного процесса в фиброзной капсуле и паренхиме печени. Иногда у больных в этой стадии появляются недомогание, периодические боли в области сердца, одышка, потеря массы тела.

Одним из важных симптомов является медленно растущее опухолевидное образование. Пальпаторно печень неодинаковой консистенции: эластичная, мягкая при поверхностном расположении кисты, плотная - при локализации кисты в глубине паренхимы.

Однако даже в далеко зашедших случаях заболевание может протекать относительно благоприятно, не причиняя серьезных неудобств больному.

Приводим клиническое наблюдение (кафедра тропических и паразитарных болезней РМАПО, доц. Т. Н. Константинова)

Больная 10 лет, поступила в хирургическое отделение детской больницы с диагнозом «гемангиома печени».

Состояние девочки при поступлении удовлетворительное. Жалобы на периодические боли в правом 
подреберье. Печень увеличена за счет левой доли, пальпируется опухолевидное эластичное образование размером 4 × $5 \mathrm{~cm}$.

Из анамнеза установлено, что девочка постоянно живет с родителями в Баку. Летом выезжает в сельскую местность к родственникам. С 3-х лет ребенка периодически беспокоили кратковременные боли в животе. Обследована, сделана холецистография, установлена дискинезия желчевыводящих путей по гипотоническому типу. В последующие годы боли в области правого подреберья продолжали беспокоить, но расценивались как следствие дискинезии. Проводились физиотерапия и грязелечение. Год назад мать обнаружила у девочки опухолевидное образование в области правого подреберья. При сканировании печени выявлено очаговое поражение в области пятого-шестого сегментов, которое расценено как гемангиома. В больнице в г. Москве при ультразвуковом исследовании органов брюшной полости выявлены 3 гипоэхогенных образования (в правой и левой долях печени) с четкими контурами, имеющие оболочку. Заподозрен эхинококкоз печени и рекомендована консультация паразитолога.

При обследовании на кафедре тропических и паразитарных болезней Российской медицинской академии последипломного образования (РМАПО) подозрение на эхинококкоз подтвердилось, исследование сыворотки крови с использованием иммуно-ферментного анализа (ИФА) с эхинококковым антигеном дали положительные результаты в титре 1:6400. Рентгенограмма легких патологических проявлений не выявила.

Установлен клинический диагноз - «Эхинококкоз печени». Больная подвергнута оперативному вмешательству: произведена эхинококкэктомия с частичным иссечением фиброзной капсулы. Во время операции обнаружены 3 эхинококковые кисты. Одна из них на нижней поверхности левой доли печени размером $4 \times 5 \mathrm{~cm}$, две в правой доле печени. Послеоперационное течение гладкое. На 23 сутки после операции выписана в удовлетворительном состоянии.

Через 3 года поступила для контрольного обследования. Состояние удовлетворительное, жалоб нет, кожа, слизистая зева чистая, в легких дыхание везикулярное, хрипов нет. Живот мягкий, не вздут, печень и селезенка в пределах нормы. На рентгенограмме легких патологии не выявлено. При УзИ печени в области 6 сегмента выявлена киста диаметром 2 см. Заключение: эхинококкоз печени, рецидив. Исследована кровь методом ИФА с эхинококковым антигеном, результат положительный в титре 1:3200. Клинический анализ крови - без патологии. Функциональные пробы печени в пределах нормы. Больная поступила для проведения терапии альбендазолом. Лечение перенесла хорошо. Достигнут положительный эффект. Киста спалась.

В стадии осложнений прослеживается развернутая клиническая картина эхинококкоза. Кисты, достигшие больших размеров, вызывают значительные патологические изменения.

При локализации кист в задних отделах печени часто происходит сдавление крупных сосудов. Развивается застой в системе воротной вены, что приводит к асциту и расширению вен живота, появлению отеков нижних конечностей. В этой стадии часто наблюдается желтушность кожных покровов и склер.

При множественном поражении клиническое течение значительно тяжелее, чем при одиночном. Кроме осложнений, связанных с механическим сдавлением и инфицированием, часто встречаются аллергические реакции по типу гиперергических. Присоединяются осложнения, чаще всего нагноение и перфорация кист. Инфицируются обычно мертвые кисты (чаще у взрослых). Клинически этот процесс сопровождается повышением температуры, ознобами, сильным потоотделением, болями и тяжестью в верхней половине живота, слабостью, лейкоцитозом, палочкоядерным сдвигом, эозинофилией.

Перфорация эхинококковых кист печени - одно из тяжелых осложнений, которое приводит к значительному ухудшению состояния, а иногда к летальному исходу. Разрываются как нагноившиеся, так и не нагноившиеся кисты. Причиной разрыва могут быть любые механические факторы (ушиб живота, резкое движение, кашлевой толчок). Иногда возможен самопроизвольный разрыв кисты. Перфорация может оставаться незамеченной, если отверстие очень маленькое и особенно, если прорыв произошел в пищеварительный тракт (желудок, кишечник).

Направление разрыва кист зависит от их локализации. Кисты, расположенные в нижних передних отделах печени, прорываются в брюшную полость, диафрагмальные - в плевральную полость. При выбросе большого количества эхинококковой жидкости развивается анафилактический шок, который выражается в том, что через несколько минут после разрыва наступает коматозное состояние, судороги, расширение зрачков, расстройство дыхания, повышение температуры до $39-40^{\circ} \mathrm{C}$, и в ближайшие часы может наступить летальный исход. Вместе с жидкостью выбрасываются сколексы, что ведет к обсеменению и образованию множества новых пузырей. При поддиафрагмальной локализации под влиянием токсического и механического действия кист развиваются слипчивый плеврит и атрофия диафрагмы. В этом случае прорыв содержимого кисты может произойти в легочную ткань и бронх.

Весьма тяжелые симптомы появляются при прорыве кисты в желчные пути. При этом развивается состояние, напоминающее приступ желчекаменной болезни с явлениями холангита (резкие боли, озноб, лихорадка).

\section{Эхинококкоз легких}

Начальному периоду свойственен полиморфизм клинических проявлений. Наиболее важным симптомом является кровохарканье, возникающее вследствие деструктивных изменений в мелких сосудах, окружающих кисты. Иногда заболевание начинается с сухого упорного ночного кашля, который постепенно нарастает и не поддается медикаментозному воздействию. Постепенно кашель становится влажным. Боли в раннем периоде бывают колющие, щемящие, ноющие. Иногда наблюдаются аллергические проявления. 
Приводим еще одно клиническое наблюдение (кафедра тропических и паразитарных болезней РМАПО, доцент Т.Н. Константинова)

Ребенок 9 лет направлен на консультацию к паразитологу для исключения эхинококкоза. Из анамнеза известно, что уже в течение месяца больного беспокоит сухой кашель (чаще по ночам) с отхождением скудного количества мокроты с прожилками крови. Рентгенография органов грудной клетки: слева в прикорневой зоне легкого имеется округлая, с четкими контурами, гомогенная тень размерами 5 × 5 см, подозрительная на доброкачественную опухоль или эхинококковую кисту.

Эпиданамнез. Ребенок с родителями жил в Павлодарской области (Казахстан) в течение 3-х лет. Семья имела частный дом, занималась разведением овец. Отец по специальности тракторист, мать - домашняя хозяйка. В момент обследования ребенка семья жила уже в Московской области.

Объективно. Ребенок правильного телосложения, достаточного питания, кожные покровы чистые, периферические лимфатические узлы не увеличены. Над всей поверхностью легких перкуторно вызывается легочный звук, выслушивается везикулярное дыхание. Хрипы не прослушиваются. Живот мягкий, не вздут. Печень, селезенка в пределах нормы. При проведении УзИ органов брюшной полости патологии не выявлено. Результат ИФА с эхинококковым антигеном положительный в титре 1:6400. Установлен клинический диагноз: «Эхинококкоз гидатидный правого легкого». Ребенок оперирован. Во время операции обнаружено опухолевидное образование диаметром 5 см, располагающееся на задней стенке левой половины грудной клетки, тесно спаянное с аортой. Образование удалено. Гистологическое заключение: «Гидатидный эхинококкоз». Послеоперационное течение гладкое. Ребенок выписан из клиники в удовлетворительном состоянии. В последующие 5 лет находился под наблюдением паразитолога и хирурга. Рецидивов не было, результаты иммунологического исследования отрицательные, снят с учета.

В период развернутой клинической картины (при наличии кисты значительных размеров) отмечается деформация грудной клетки, межреберные промежутки сглажены. Грудная клетка на стороне поражения отстает при дыхании или в нем не участвует. Перкуторно выявляется притупление легочного звука в соответствующей зоне, ослабление дыхания. При возникновении перифокального воспаления прослушиваются сухие и влажные хрипы, при вовлечении в процесс плевры - шум трения плевры. Большие кисты вызывают смещение органов средостения, возможно сдавление ими крупных сосудов, что приводит к застойным явлениям. По мере развития процесса кашель усиливается и становится влажным, присоединяется одышка. Перфорация кист в легких у детей встречается достаточно редко.

В клинической картине эхинококкоза других органов доминируют симптомы, наводящие на мысль о новообразовании. При нагноении кист развиваются разнообразные симптомы (в зависимости от локализации паразита). Особенно тяжело протекает эхинококкоз головного и спинно- го мозга (первичный или перешедший из тел позвонков). Локализация кисты в глазнице приводит к развитию проптоза. При формировании кисты в костях поцесс начинается в костномозговой полости, откуда киста прорастает в ткань кости, поражая иногда ее значительные участки. Ее развитие становится достаточно нетипичным, т. к. не формируется ограничивающая кисту мембрана.

\section{Диагностика}

Однокамерный эхинококкоз подозревают у лиц, которые имеют опухолевидное медленно растущее образование в печени, легких или других органах. При этом в анамнезе больные часто (но не обязательно!) указывают на контакт с собаками, проживание в очагах эхинококкоза.

Изменения лабораторных показателей при эхинококкозе неспецифичны. У части больных при нормальном количестве лейкоцитов в той или иной степени повышается количество эозинофилов, отмечается увеличение СОЭ. При множественном процессе общее содержание белка несколько увеличивается, изменяется состав белков сыворотки крови: возникает умеренная гипоальбуминемия и повышается концентрация гамма-глобулинов.

\section{Инструментальные методы}

При диагностике (Черкасский, 1994; Абдуфатаев, 2002; Авдюхина и др., 1995; Зикриллаев, 2002; Котлобовский и др., 2003; Сухарева, 2014) эхинококкоза в современных условиях самую большую диагностическую ценность имеют лучевые методы, причем на первое место следует поставить ультразвуковые исследования (сонографию). Из методов рентгенологического исследования применяется рентгенография в прямой и боковой проекциях, симультанная (послойная) томография, компьютерная томография, по специальным показаниям - бронхография. Радионуклидные методы в настоящее время применяются крайне редко (по специальным показаниям) из-за большей эффективности и безвредности ультразвукового исследования (сонографии).

При неосложненном эхинококкозе эхинококковая киста рентгенологически дает овальную, реже округлую, гомогенную более или менее интенсивную тень с четкими краями на фоне светлой легочной ткани. Судить о форме кисты можно лишь после исследования в двух взаимно перпендикулярных проекциях. Интенсивность тени необызвествленной эхинококковой кисты зависит от ее размера: кисты малого размера могут быть не видны на обычных рентгенологических снимках и выявляются только при томографии. Структура тени обычно однородная, контуры четкие, но при возникновении перифокального воспаления они становятся неровными. Ценным диагностическим признаком является рентгенологически определяемое просветление, имеющее форму вытянутого серпа, расположенного по краю кисты. Этот феномен выявляется в 30\% случаев и наблюдается при проникновении воздуха между хитиновой оболочкой паразита и фиброзной оболочкой, отграничивающей паразита от окружающей легочной ткани. При прорыве кисты в бронх появляется горизонтальный уровень жидкости и газовый пузырь над ней. Иногда вместо горизонтального уровня жидкости наблюдается волнистость или выпук- 
лость, и при наклоне больного уровень жидкости не меняется. Это обусловлено спадением хитиновой оболочки паразита. Спавшаяся оболочка плотно охватывает оставшуюся в кисте жидкость. Указанное явление описано под названием «плавающей мембраны». В этих случаях наиболее четко выявляется «симптом расщепления контура». При отхождении всего содержимого можно обнаружить кольцевидную тень, соответствующую фиброзной капсуле. Прорыв эхинококковой кисты в плевральную полость рентгенологически вначале напоминает картину, наблюдаемую при экссудативном плеврите. Одним из признаков гибели паразита служит обызвествление оболочек кисты. Процесс обызвествления не всегда идет равномерно, поэтому нередко тень становится крапчатой, позже появляются полоски, сначала окаймляющие ее частично, позже - на всем протяжении.

Компьютерная томография дает возможность отметить морфологические различия однокамерного и многокамерного эхинококкоза. На компьютерных сканограммах паразитарные кисты видны в виде округлых образований с четкими ровными контурами. При обызвествлении кисты четкость контуров увеличивается. Большие кисты содержат внутри хорошо заметные дочерние пузыри.

Лапароскопия является диагностическим методом, доступным для всех хирургических отделений, однако он позволяет подтвердить или отвергнуть диагноз эхинококкоза только в случае, если патологическое образование расположено близко к видимой поверхности органа.

Ценность иммунодиагностики заключается в возможности не только подтверждения диагноза однокамерного эхинококкоза при выраженных клинических проявлениях, но и раннего выявления данной патологии. В настоящее время используют иммуноферментный анализ (ИФА). В России выпускают коммерческую тестсистему на основе ИФА «Эхинококкоз Ig-стрип» в ЗАО «Вектор-Бест» (Новосибирск).

Иммунологические реакции становятся положительными на 7-21 день после заражения, максимальные титры определяются к 60-150 дню. После радикального хирургического вмешательства титры снижаются, но могут не достигать нормы до 3 лет. У части реконвалесцентов низкие положительные титры сохраняются в течение многих лет.

Эффективность иммунодиагностики зависит не только от чувствительности и специфичности иммунодиагностического теста, но и от иммунного статуса хозяина, степени развития патологического процесса.

Кроме ранней стадии развития паразита, низкие титры могут быть при легочной локализации, обызвествлении оболочек ларвоцист и гибели паразита, а также в поздней, неоперабельной стадии.

\section{Паразитологическая диагностика}

Содержимое эхинококкового пузыря при разрыве может излиться в просвет полых органов (кишечник, бронхи) и выделиться наружу. Тогда представляется возможность паразитологического подтверждения диагноза по наличию сколексов, отдельных крючьев, которые нередко отрываются от сколексов, и иногда - «дочерних» пузырей. Чаще всего эти элементы выявляются в мокроте, асцитической жидкости, иногда - в дуоденальном содержимом, моче (крайне редко). Они могут быть обнаружены также в жидкости, полученной во время хирургической операции.

Фрагменты оболочек эхинококкового пузыря, извлеченные во время операции или отошедшие самостоятельно, могут быть идентифицированы под микроскопом.

\section{Лечение}

Основным методом лечения эхинококкоза остается хирургический (Назыров, 1999; Коваленко, 1998; Пулатов, 2002; Шишкин, 1992). Пузырь удаляют вместе с оболочками. При этом стремятся не допустить вторичного обсеменения содержимым пузыря операционной раны и полостей (брюшной, плевральной). Для этого пузыри по возможности удаляют целиком, не повреждая оболочки. Если это не удается, жидкость осторожно эвакуируют, не допуская ее попадания в рану. После пункционной аспирации жидкого содержимого кисты в ее полость вводят равное количество $80 \%$ стерильного глицерина, выдерживают 10 мин, опорожняют полость кисты от глицерина и производят открытую эхинококкэктомию. Затем остаточную полость заполняют глицерином той же концентрации с экспозицией 10 минут. После эвакуации глицерина остаточную полость ушивают и дренируют. Так же можно удалять и нагноившиеся кисты.

Проведенные новейшие экспериментальные и клинические исследования, посвященные эхинококкозу, выявили высокую чувствительность зародышевых элементов паразита к лазерному и ультрафиолетовому излучению. Было четко показано, что фиброзная капсула проницаема для зародышевых элементов паразита и микроорганизмов. В связи с этим следует считать нецелесообразным оставлять ее при хирургическом лечении эхинококкоза, при возможности необходимо ее полное удаление.

При хирургическом лечении эхинококкоза печени и легких наиболее целесообразно использование лазерных скальпелей в сочетании с низкоинтенсивным лазерным излучением.

Это обеспечивает как высокий асептический, гемостатический, паразито- и микробоцидный эффект, так и стимуляцию репаративных процессов. При этом ультразвук, вызывая необратимые изменения зародышевых элементов, обладает и самой высокой паразитоцидностью. Для обеззараживания ложа паразита и фиброзной капсулы в случае невозможности ее удаления наиболее целесообразно использование ультразвука. Однако такое оперативное лечение доступно только специализированным учреждениям.

Особые подходы при проведении оперативного лечения приходится применять при эхинококкозе головного и спинного мозга, глазницы, поражении костей, почек и других органов.

Полученные новые данные по функциональной морфологии ларвоцисты позволяют предполагать проницаемость ее структур для высокомолекулярных соединений, что следует принять во внимание при разработке методов медикаментозной терапии эхинококкоза. Ламинарная оболочка, являясь производной паразита, 
принимает участие в транспорте высокомолекулярных соединений.

Фармакотерапия эхинококкоза разрабатывается много лет (Энциклопедия..., 2003).

В настоящее время используют Альбендазол (Albendazol), выпускающийся в России в г. Уфе (Башкортостан). Это метиловый эфир карбаминовой кислоты. Он тормозит поглощение гельминтами глюкозы, что приводит к истощению запасов гликогена и понижению образования АТФ. Все это в конечном итоге вызывает снижение репродуктивности и жизнеспособности гельминтов и приводит их к гибели.

Форма выпуска: таблетки белого с желтоватым или сероватым оттенками цвета по 200 мг $(0,2)$ по 6 или 10 таблеток в контурной ячейковой упаковке.

Условия хранения: список Б.

Принимают внутрь после еды, таблетки не разжевывают, запивают водой. Суточная доза составляет $10 \mathrm{Mr} \backslash к г$ массы тела. Не применяют для лечения детей в возрасте до 2 лет. После приема альбендазола применения слабительных средств и специальной диеты не требуется.

Курс лечения состоит из нескольких 28-дневных циклов с интервалами между ними от 14 дней до 1 месяца. Число циклов на курс определяется строго индивидуально для каждого больного.

Фармакотерапия показана в ранней стадии, до развития выраженных нарушений иммунологического статуса. К назначению лекарственной терапии следует подходить с осторожностью, помня, что гибель эхинококка может привести к осложнениям (нагноение и разрыв кисты). В связи с этим наиболее разумно сочетать хирургическое и лекарственное лечение, назначая препарат до и после операции для предотвращения диссеминации сколексов гельминта из-за нарушения целостности пузыря.

Существует противорецидивная фармакотерапия, которая проводится после удаления нескольких кист, сразу после разрыва кисты и ее удаления. Число циклов на курс определяется строго индивидуально для каждого больного.

При небольших кистах и при невозможности удалить их оперативным методом фармакотерапию применяют как единственный метод лечения. В этом случае применяют также альбендазол, в той же суточной и цикловой дозировке, но курс лечения по рекомендации ВОЗ должен состоять не менее, чем из 9-10 циклов (его общая продолжительность в этом случае достигает 18 месяцев).

При нарушении функции печени проводят симптоматическую терапию, при нагноении назначают антибиотики.

\section{Диспансеризация}

Лица, у которых были выявлены положительные иммунологические реакции или клинические проявления эхинококкоза, подлежат углубленному клиническому обследованию с целью определения локализации процесса. При подтверждении диагноза больных направляют на лечение. При отсутствии указаний на наличие кисты, но при положительных иммунологических реакциях за этими лицами устанавливается диспансерное наблю-

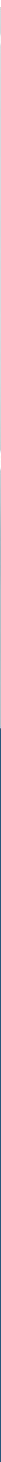


дение с клинико-иммунологическими обследованиями ежегодно или 1 раз в 2 года.

Больные эхинококкозом в послеоперационном периоде должны находиться на диспансерном учете в течение 8-10 лет и обследоваться не реже 1 раза в 2 года. При множественном эхинококкозе с осложненным течением больные обследуются ежегодно. Обследование включает общий анализ крови, мочи, определение билирубина сыворотки крови, тимоловой пробы, протромбина, общего белка и белковых фракций, аминотрансфераз (АЛТ и АСТ), щелочной фосфатазы, иммунологические реакции на эхинококкоз. Применяют и инструментальные методы обследования, ультразвуковую томографию (сонографию), рентгенографию и симультанную томографию органов грудной клетки, компьютерную томографию, рентгенографию костей.

При отсутствии в течение 5 лет у пациента, подвергнутого диспансеризации, клинико-лабораторных, инструментальных признаков рецидива, наличии стабильно отрицательных иммунологических реакций, его снимают с учета.

В случае повышения титров иммунологических реакций, появления клинических признаков заболевания вновь показано обследование в стационаре.

После удаления множественных эхинококковых кист больные нетрудоспособны в течение 4-6 месяцев, единичных кист - в течение 2-3 месяцев. Вопрос о трудоспособности пациента в каждом случае решается индивидуально.

\section{Эпидемиология}

Окончательными хозяевами, у которых возбудитель однокамерного эхинококкоза паразитирует в стадии половозрелой мелкой цестоды, являются собаки и другие представители семейства псовых (волки, шакалы, лисицы, гиены), реже - кошачьих (львы, леопарды, рыси и др.). В случае интенсивной инвазии поверхность фекалий собак бывает покрыта белой пленкой, состоящей из члеников цестод. С фекалий зрелые членики расползаются на расстояние до 25 см, загрязняя все вокруг яйцами гельминта. У собаки активное выползание члеников вызывает зуд, и она вылизывается и трется, загрязняя собственную шерсть и различные предметы, почву садов и огородов, а через все это - промежуточных хозяев (овец, оленей, коров, лошадей, верблюдов, слонов, человека, домашнюю птицу).

Промежуточными хозяевами, в организме которых развивается личиночная стадия гельминта, являются

Сведения об авторах:

1. Ромих Виктория Валериевна - заведующий лабораторией уродинамики и функциональных расстройств органов таза НИИ урологии и интервенционной радиологии им. Н.А. Лопаткина - филиал ФГБУ «НМИРЦ» Минздрава России

2. Сафаров Равшан Мухитдинович-д.М.Н., профессор, заведующий консультативным отделом НИИ урологии и интервенционной радиологии им. Н.А. Лопаткина - филиал ФГБУ «НМИРЦ» Минздрава России

3. Поляков Василий Евгеньевич - д.м.Н., профессор, научный консультант НИИ урологии и интервенционной радиологии им. Н.А. Лопаткина - филиал ФГБУ «НМИРЦ» Минздрава России

Исследования и практика в медицине. 2015, т. 2, №1, с.27-35 главным образом овцы, а также крупный рогатый скот, свиньи, верблюды и человек. Человек заражается многими путями: через грязные руки, воду, пищу. Однако главным конечным фактором передачи без сомнения являются грязные руки. Они загрязняются непосредственно при контакте с собаками или опосредованно через различные субстраты, на которые попадают частицы фекалий собак, нередко через овечью шерсть. Яйца эхинококка могут разноситься птицами, насекомыми (тараканами и мухами), не теряя в их кишечнике жизнеспособности.

Онкосферы эхинококка могут сохранять жизнеспособность в окружающей среде до 6 месяцев, они плохо переносят прямые солнечные лучи и замораживание. Обычные дезинфекционные средства неэффективны, только кипячение в течение 20 сек. вызывает гибель онкосфер.

По регистрируемым данным, заболеваемость эхинококкозом однокамерным увеличивается с возрастом. Многие больные заражаются в детстве, но болезнь у них обнаруживается позднее - в подростковом возрасте или в более старшем. К числу регионов, эндемичных в отношении эхинококка, относятся Австралия, Новая Зеландия, Южная Америка, Северная Африка, Иран, Казахстан, Монголия, Турция, юг Украины, Крым, Молдавия, Северный Кавказ, Закавказье, Туркмения, Узбекистан. В России такими регионами являются Бурятия, горнотаежная зона Дальнего Востока, Чукотка, Якутия. Например, уровень пораженности людей в Узбекистане составляет в среднем от 6 до 9 человек на 1000 населения и не имеет тенденции к снижению. Количество операций, проводимых в Узбекистане по поводу эхинококкоза, составляет от 1000 до 1500 в год, число осложненных форм этого заболевания достигает 25-45\%, летальность при оперативном лечении удерживается на уровне 2,5$7 \%$ и более.

Профилактика эхинококкоза - медико-ветеринарная проблема, которая должна решаться комплексно. Ведущими мерами являются, с одной стороны, недопущение скармливания собакам боенских отходов (в частности, внутренностей овец, свиней, лошадей, крупного и мелкого рогатого скота), с другой - плановая, регулярная дегельминтизация собак. Необходимо уменьшение в разумных пределах контактов взрослых и детей с собаками, особенно используемых для охраны отар овец, пасущихся стад крупного и мелкого рогатого скота, табунов лошадей. Важно соблюдение правил личной гигиены.

Information about the authors:

1. Romikh V.E. - head of department of urodynamics and functional disorders of pelvis N. Lopatkin SRIUIR

2. Safarov R.M. - MD, professor, head of the advisory N. Lopatkin SRIUIR

3. Polyakov V.E. - MD, professor, scientific advisory N. Lopatkin SRIUIR 
1. Абдиев Т. А., Вахабов Т. А., Журавлева Н. А. и др. Прогноз изменения ситуации по эхинококкозу среди населения в Узбекистане.//Медицинская паразитология и паразитарные болезни. 2000. № 3. С. 53-55.

2. Абдуфатаев Т. А. Нереспираторные функции легких при эхинококкозе легких у детей.//Детская хирургия. 2002. № 3. С. 40-44.

3. Авдюхина Т.И., Горбунова Ю. П., Константинова Т. Н., Алексеева М.И. Лабораторная диагностика гельминтозов. Ч. ІІ. Цестодозы и трематодозы. М.: РМАПО. 1955. 55 с.

4. Алиев Б.С., Ордабеков С. О. Осложненный эхинококкоз органов брюшной полости. Алма-Ата: Гылым. 1996. 216 с.

5. Ветшев П.С., Мусаев Г.Х. Эхинококкоз: современное состояние проблемы.//Анналы хирургической гепатологии. 2006. № 11. С. 111-117.

6. Ветшев П.С., Мусаев Г.Х., Бруслик С. В. Эхинококкоз: современное состояние проблемы.//Украинский журнал хирургии. 2013. № 3. С. 196-201.

7. Зикриллаев 3. Гидатидозный эхинококкоз паравезикальной клетчатки, симулировавший водянку оболочек яичка.//Урология. 2002. № 3. С. 55-55

8. Коваленко Ф.П. Экспериментальные модели и эхинококкозов: оптимизация и применение в разработке новых методов диагностики, профилактики и лечения эхинококкозов человека и животных.//Автореферат дисс. доктора мед. наук./M, 1998. 59 с

9. Котлобовский В.И., Досмагамбетов С. П., Дженалаев Б.К. и др. Результаты хирургического лечения эхинококкоза печени у детей.//Детская хирургия. 2003. № 5. С. 17-20.

\section{References:}

1. Abdiev T. A., Vahabov T. A., Zhuravleva N. A. i dr. Prognoz izmenenija cituacii po jehinokokkozu sredi naselenija $v$ Uzbekistane.//Medicinskaja parazitologija i parazitarnye bolezni. 2000. № 3. S. 53-55. Russian.

2. Abdufataev T. A. Nerespiratornye funkcii legkih pri jehinokokkoze legkih u detej.//Detskaja hirurgija. 2002. № 3. S. 40-44. Russian.

3. Avdjuhina T.I., Gorbunova Ju.P., Konstantinova T. N., Alekseeva M. I. Laboratornaja diagnostika gel'mintozov. Ch. II. Cestodozy i trematodozy. M.: RMAPO. 1955. 55 s. Russian.

4. Aliev B.S., Ordabekov S. O. Oslozhnennyj jehinokokkoz organov brjushnoj polosti. Alma-Ata: Gylym. 1996. 216 s. Russian.

5. Vetshev P.S., Musaev G.H. Jehinokokkoz: sovremennoe sostojanie problemy.//Annaly hirurgicheskoj gepatologii. 2006. № 11. S. 111-117. Russian.

6. Vetshev P.S., Musaev G. H., Bruslik S. V. Jehinokokkoz: sovremennoe sostojanie problemy.//Ukrainskij zhurnal hirurgii. 2013. № 3. S. 196-201. Russian.

7. Zikrillaev Z. Gidatidoznyj jehinokokkoz paravezikal'noj kletchatki, simulirovavshij vodjanku obolochek jaichka.//Urologija. 2002. № 3. S. 55-55. Russian.

8. Kovalenko F.P. Jeksperimental'nye modeli i jehinokokkozov: optimizacija i primenenie $v$ razrabotke novyh metodov diagnostiki, profilaktiki i lechenija jehinokokkozov cheloveka i zhivotnyh.//Avtoreferat diss. doktora med. nauk./M, 1998. 59 s. Russian.

9. Kotlobovskij V.I., Dosmagambetov S.P., Dzhenalaev B. K. i dr Rezul'taty hirurgicheskogo lechenija jehinokokkoza pecheni u detej.//Detskaja hirurgija. 2003. № 5. S. 17-20. Russian.
10. Лысенко А.Я. (Ред.) Клиническая паразитология. Руководство. Женева: ВОЗ. 2002. 752 с

11. Назыров Ф.Г., Исмаилов Д.А., Леонов Ф.В., Байбеков И.М. Эхинококкоз (Морфологическое обоснование хирургического лечения). Ташкент: Из-во медицинской литературы им. Абу Али ибн Сино. 1999. 207 с.

12. Поляков В.Е., Лысенко А. Я. Гельминтозы у детей и подростков. М.: Медицина. 2003. 256 с.

13. Пулатов А. Т. Эхинококкоз IY сегмента печени у детей.//Детская хирургия. 2002. № 5. С. 11-17.

14. Сергиев В.П., Легоньков Ю. А., Полетаева О.Г. и др. Эхинококкоз цистный (однокамерный): клиника, диагностика, лечение, профилактика. М: Векторбест. 2008. 36 с.

15. Скрябин К.И., Шульц Р.- Эд.С. Гельминтозы человека. Часть І. М. - Л.: Госмедгнз. 1929. 376 с.

16. Сухарева Г.Э. Эхинококкоз сердца у ребёнка.//Здоровье ребёнка. 2014. № 55. URL: http://www.mif-ua. com/archive/article/38906 (Дата обращения 01.02.2015г.)

17. Черкасский Б. Л. Инфекционные и паразитарные болезни человека. Справочник эпидемиолога. М: Медицинская газета. 1994. $617 \mathrm{c}$.

18. Шишкин М.А. Экспериментально-клиническое обоснование применения высоко- и низкоинтенсивного лазерного излучения в хирургии эхинококкоза легких./Автореф. дис. канд. мед. наук/М. 1992.z

19. Энциклопедия лекарств. Изд. 10 перераб. и дополн. М. 2003

10. Lysenko A.Ja. (Red.) Klinicheskaja parazitologija. Rukovodstvo. Zheneva: VOZ. 2002. 752 s. Russian.

11. Nazyrov F. G., Ismailov D. A., Leonov F. V., Bajbekov I. M. Jehinokokkoz (Morfologicheskoe obosnovanie hirurgicheskogo lechenija). Tashkent: Iz-vo medicinskoj literatury im. Abu Ali ibn Sino. 1999. 207 s. Russian.

12. Poljakov V.E., Lysenko A.Ja. Gel'mintozy u detej i podrostkov. M.: Medicina. 2003. 256 s. Russian.

13. Pulatov A. T. Jehinokokkoz IY segmenta pecheni u detej.//Detskaja hirurgija. 2002. № 5. S.11-17. Russian.

14. Sergiev V. P., Legon'kov Ju. A., Poletaeva O. G. i dr. Jehinokokkoz cistnyj (odnokamernyj): klinika, diagnostika, lechenie, profilaktika. M: Vektorbest. 2008. 36 s. Russian.

15. Skrjabin K.I., Shul'c R.- Jed.S. Gel'mintozy cheloveka. Chast' I. M. - L.: Gosmedgnz. 1929. 376 s. Russian.

16. Suhareva G.Je. Jehinokokkoz serdca u rebjonka.//Zdorov'e rebjonka. 2014. № 55. URL: http://www.mif-ua.com/archive/article/38906 (Data obrashhenija 01.02.2015g.). Russian.

17. Cherkasskij B.L. Infekcionnye i parazitarnye bolezni cheloveka. Spravochnik jepidemiologa. M: Medicinskaja gazeta. 1994. 617 s. Russian.

18. Shishkin M.A. Jeksperimental'no-klinicheskoe obosnovanie primenenija vysoko- i nizkointensivnogo lazernogo izluchenija v hirurgii jehinokokkoza legkih./Avtoref. dis. kand. med. nauk/M. 1992. Russian.

19. Jenciklopedija lekarstv. Izd. 10 pererab. i dopoln. M. 2003. Russian. 